\title{
PERAN GENDER DALAM PENGAMBILAN KEPUTUSAN PADA ERA REFORMASI DI INSTITUSI KEPOLISIAN
}

\author{
Novita Wahyu Setyawati dan Endah Prawesti Ningrum \\ Universitas Bhayangkara Jakarta Raya \\ fara kitty@yahoo.com
}

\begin{abstract}
The Police are in the process of reforming the gender, namely the change of a police organization into a professional and responsible police force and implement a policing style that is responsive to the needs of the local community. Where in the act of finding solutions and decision-making field did not see any differences between men and women.

The purpose of this study is to examine the role of gender in decision making in the reform era in Police institution (South Bekasi Police Station case study).

Analytical methods used are qualitative, through the stages of data interpretation, data reduction, data preparation, examination of data validity, and draw conclusions.

The new view that women have equal rights and opportunities and their potential will expand the space for women and the presence of female figures in the public dimension, to be treated proportionally and not to rule out their opinions and make decisions.
\end{abstract}

Keywords: Gender Roles and Decision Making.

\section{PENDAHULUAN}

\section{Latar Belakang Masalah}

Organisasi kepolisian memainkan peran penting dalam masyarakat. Mereka bertanggung jawab memelihara perdamaian dan ketertiban, dengan menegakkan rule of law dan menjalankan tugas mereka dengan kepekaan dan perhatian terhadap para anggota masyarakat. Karena organisasiorganisasi ke polisian di seluruh dunia berusaha meningkatkan respons dan perlindungan mereka terhadap individu dan masyarakat, mereka jadi terlibat dalam proses reformasi kebijakan dan praktek. Tuntutan untuk reformasi didorong oleh sejumlah faktor seperti: pengkajian ulang internal, tekanan publik, keputusan-keputusan pemerintah, perhatian internasional dan/atau pemulihan pasca-konflik. Proses reformasi kepolisian mendukung pembentukan atau penguatan organisasi kepolisian yang bertanggung jawab, efektif, adil dan menghormati hak-hak.

Peran gender berfokus pada reformasi kepolisian, dimana pentingnya penguatan kemampuan kepolisan dalam memahami dan menangani kebutuhan keamanan yang berbeda dari seluruh penduduk (yang mencakup pria, wanita, anak lelaki dan anak perempuan dari semua bidang pekerjaan) dan menciptakan lembaga kepolisian yang nondiskriminatif dan representatif.

Fenomena yang ada mengenai isu-isu gender, Pertama, istilah gender seringkali dirancukan dengan istilah jenis kelamin. Padahal istilah gender bukan hanya 
menyangkut jenis kelamin perempuan, melainkan juga jenis kelamin laki-laki. Kedua, pemahaman dan pembedaan antara konsep seks dan gender sangatlah diperlukan dalam melakukan analisis untuk memahami persoalan-persoalan ketidakadilan sosial yang menimpa perempuan.

Isu gender bukan merupakan suatu proses merampas kekuasaan dari pria dan kemudian memberikannya kepada wanita. Akan tetapi sebaliknya merupakan suatu proses meningkatkan efisiensi dan efektivitas organisasi-organisasi yang diperbarui.

Fenomena yang ada saat ini dilingkungan kepolisian, pada kenyataannya, polisi wanita sering memberikan sejumlah keterampilan dan kekuatan tertentu bagi tugas kepolisian, seperti:

1. Polisi wanita mungkin lebih efektif dalam meredam situasi yang mungkin berbahaya daripada polisi pria.

2. Polisi wanita lebih jarang dilaporkan masyarakat bertindak "tidak patut" dibandingkan dengan polisi pria.

3. Polisi wanita lebih jarang menggunakan kekuatan yang mematikan, seperti menggunakan senjata api.

4. Polisi wanita lebih jarang mengalami penentangan atau perlawanan dari tersangka pria yang mereka tangkap dan/atau tanyai.

5. Polisi wanita sering memiliki keterampilan komunikasi yang lebih baik daripada polisi pria dan lebih mampu mendapatkan kerja sama dan kepercayaan yang diperlukan untuk melaksanakan suatu model perpolisian masyarakat.

Melihat adanya fenomena mengenai isuisu gender, alasan peneliti mengambil studi kasus di institusi kepolisian dikarenakan saat ini polisi sedang melakukan reformasi gender yaitu perubahan suatu organisasi kepolisian menjadi kepolisian yang profesional dan bertanggung jawab dan menerapkan gaya perpolisian yang tanggap terhadap kebutuhan masyarakat setempat. Dimana dalam tindakan mencari solusi dan pengambilan keputusan dilapangan tidak memandang ada perbedaan antara kaum pria dan wanita.

Berdasarkan fenomena yang ada dan alasan penelitian, maka peneliti tertarik untuk melakukan penelitian yang berjudul Peran Reformasi Gender dalam Pengambilan Keputusan di Lingkungan Kepolisian (Studi Kasus Polsek Bekasi Selatan).

\section{Rumusan Masalah}

Rumusan masalah dari penelitian ini mengkaji mengenai peran gender dalam pengambilan keputusan pada era reformasi di institusi Kepolisian (studi kasus Polsek Bekasi Selatan).

\section{Tujuan Penelitian}

Tujuan penelitian ini, untuk mengkaji mengenai peran gender dalam pengambilan keputusan pada era reformasi di institusi 
Kepolisian (studi kasus Polsek Bekasi Selatan).

\section{Manfaat Penelitian}

Adapun manfaat penelitian:

a. Bagi masyarakat

$\begin{array}{llr}\text { Memberikan } & \text { penjelasan } & \text { kepada } \\ \text { masyarakat } & \text { umum bahwa kaum }\end{array}$ perempuan bukan merupakan salah satu faktor penghambat di tempat kerja serta kesamaan pandangan dalam kesetaraan gender diikuti dengan keadilan.

b. Bagi Akademisi

Mencari kebenaran melalui pengumpulan data dari lapangan tentang adanya perlakuan gender di tempat bekerja, serta menjadi acuan bagi penelitian berikutnya.

c. Bagi Peneliti

Melanjutkan penelitian ini ke tahap jurnal nasional maupun internasional.

\section{TINJAUAN TEORI}

\section{Peran Gender}

Mufidah dalam Paradigma Gender mengungkapkan bahwa pembentukan gender ditentukan oleh sejumlah faktor yang ikut membentuk, kemudian disosialisasikan, diperkuat, bahkan dikonstruksi melalui sosial atau kultural, dilanggengkan oleh interpretasi agama dan mitosmitos seolah-olah telah menjadi kodrat laki-laki dan perempuan.

Gender merupakan analisis yang digunakan dalam menempatkan posisi setara antara laki-laki dan perempuan untuk mewujudkan tatanan masyarakat sosial yang lebih egaliter. Jadi, gender bisa dikategorikan sebagai perangkat operasional dalam melakukan measure (pengukuran) terhadap persoalan laki-laki dan perempuan terutama yang terkait dengan pembagian peran dalam masyarakat yang dikonstruksi oleh masyarakat itu sendiri. Gender bukan hanya ditujukan kepada perempuan semata, tetapi juga kepada laki-laki.. Hanya saja, yang dianggap mengalami posisi termarginalkan sekarang adalah pihak perempuan, maka perempuanlah yang lebih ditonjolkan dalam pembahasan untuk mengejar kesetaraan gender yang telah diraih oleh laki-laki beberapa tingkat dalam peran sosial, terutama di bidang pendidikan karena bidang inilah diharapkan dapat mendorong perubahan kerangka berpikir, bertindak, dan berperan dalam berbagai segmen kehidupan sosial.

Dalam memahami konsep gender ada beberapa hal yang perlu difahami, antara lain

\section{a. Ketidak-adilan dan diskriminasi gender}

Ketidak-adilan dan diskriminasi gender merupakan kondisi tidak adil akibat dari sistem dan struktur sosial dimana baik perempuan maupun laki - laki menjadi korban dari sistem tersebut. Berbagai pembedaan peran dan kedudukan antara perempuan dan laki - laki baik secara langsung yang berupa perlakuan maupun sikap dan yang tidak langsung berupa dampak suatu peraturan perundang undangan maupun kebijakan telah 
menimbulkan berbagai ketidak-adilan yang berakar dalam sejarah, adat, norma, ataupun dalam berbagai struktur yang ada dalam masyarakat.

Ketidak-adilan gender terjadi karena adanya keyakinan dan pembenaran yang ditanamkan sepanjang peradaban manusia dalam berbagai bentuk yang bukan hanya menimpa perempuan saja tetapi juga dialami oleh laki - laki.

\section{b. Kesetaraan gender}

Kesetaraan dan keadilan gender adalah suatu kondisi dimana porsi dan siklus sosial perempuan dan laki - laki setara, seimbang dan harmonis. Kondisi ini dapat terwujud apabila terdapat perlakuan adil antara perempuan dan laki - laki. Penerapan kesetaraan dan keadilan gender harus memperhatikan masalah kontekstual dan situasional, bukan berdasarkan perhitungan secara sistematis dan tidak bersifat universal.

\section{Pengambilan Keputusan}

Pengambilan keputusan dalam dunia pekerjaan merupakan suatu bentuk keputusan baik dalam bentuk pemikiran maupun dalam bentuk tindakan. Dalam pola pengambilan keputusan kaum perempuan dan laki-laki dalam mengambil keputusan, terbagi dua pola; Pertama, pola tradisional yang memberikan kewenangan kepada kaum lakilaki untuk mengambil keputusan, dan Kedua, pola modern yang memberikan kewenangan kepada kaum perempuan dan laki-laki secara bersama-sama dalam mengambil keputusan tanpa menghilangkan peran masing-masing. (Wiwik Gusnita; 2011 : 19) Selanjutnya menurut Scanzoni dan Scanzoni yang dikutib oleh Azzachrawani bahwa pola pengambilan keputusan dalam dunia pekerjaan menggambarkan bagaimana struktur pola kekuasaan tersebut. (Wiwik Gusnita; 2011 : 18)

Dengan demikian jika gender sudah berfungsi dalam dunia pekerjaan maka pengambilan keputusan tidak lagi didominasi oleh kaum laki-laki. Maria Kaban mengatakan bahwa dalam dunia pekerjaan kesetaraan perempuan dan laki-laki dalam proses pengambilan keputusan memiliki strategis dan berdampak ganda. Strategis karena mewujudkan keseimbangan, keserasian, dan keselarasan ganda karena tidak memberikan pembedaan jenis ketika mengambil keputusan. (Maria Kaban; 2005 : 45)

Selanjutnya Syamsiah Achmad membagi dua bentuk pengambilan keputusan. Pertama; keputusan individu perempuan dan laki-laki sebagai keputusan yang ditujukan pada diri sendiri, yang mempertimbangkan kepentingan dan aspirasi diri sendiri baik secara individu maupun berkaitan dengan keluarga, masyarakat, organisasi dan lainlain. Kedua; keputusan kolektif sebagai keputusan yang diambil oleh seorang perempuan atau laki-laki bersama dengan 
para anggota kelompoknya baik secara informal maupun formal. (Maria Kaban; $2005: 46)$

Aida Vitalaya S. Hubeis mengatakan kualitas hidup sangat ditentukan oleh peran gender. Peningkatan kualitas dan kuantitas perempuan di bidang ekonomi dapat dilakukan melalui kegiatan :

1. Peningkatan kemampuan dan profesionalisme, etos dan produktivitas kerja, kewirausahaan, manajemen dan kepemimpinan.

2. Menciptakan iklim yang kondusif agar dapat berperan dalam pembangunan secara optimal.

3. Meningkatkan akses modal / kredit, informasi pasar, dan jaringan produksi serta pasar.

4. Memperoleh dukungan berbagai pihak dalam dunia usaha dengan menciptakan iklim yang kondusif untuk meningkatkan kemandirian, antara lain melalui kemitraan usaha. (Aida Vitayala S. Hubeis; 2010 : 114).

\section{PEMBAHASAN}

Peran gender dalam pengambilan keputusan pada era reformasi di institusi kepolisian (studi kasus Polsek Bekasi Selatan) suatu hal yang menarik untuk diteliti dan dikaji. Karena peran gender dalam pengambilan keputusan belum memberikan ruang yang luas bagi perempuan. Oleh karena itu penelitian ini menarik untuk dikembangkan lebih luas guna mengetahui proses peran gender dalam era reformasi di institusi kepolisian.

\section{Profil Responden}

Berdasarkan hasil data yang diperoleh dari penelitian yang dilakukan menunjukkan bahwa bahwa usia responden berusia sekitar 23-56 tahun dimana rata-rata usia tersebut masih aktif dalam bekerja. Dari profil responden lainnya mayoritas berjenis kelamin pria, untuk lama bekerja diatas 10 tahun, status responden sudah menikah, pendidikan terakhir SMA/STM, dan jabatan responden mayoritas staf. Berikut tabel profil responden: 
Tabel 3.1

Profil Responden

\begin{tabular}{|c|c|c|}
\hline No. & Pertanyaan & Jawaban \\
\hline 1. & Usia & $23-56$ tahun \\
\hline 2. & Jenis Kelamin & Pria 10 orang Wanita 4 orang \\
\hline 3. & Lama Bekerja & $\begin{array}{l}<5 \text { tahun }: 2 \text { orang } \\
<10 \text { tahun }: 2 \text { orang } \\
>10 \text { tahun }: 10 \text { orang }\end{array}$ \\
\hline 4. & Status & $\begin{array}{ll}\text { Belum Menikah } & : 2 \text { orang } \\
\text { Menikah } & : 12 \text { orang }\end{array}$ \\
\hline 5. & Pendidikan & $\begin{array}{ll}\text { SMA/STM } & : 11 \text { orang } \\
\text { S1 } & : 3 \text { orang }\end{array}$ \\
\hline 6. & Jabatan/Pangkat & $\begin{array}{ll}\text { Kepala Unit } & : 4 \text { orang } \\
\text { Staf } & : 10 \text { orang }\end{array}$ \\
\hline
\end{tabular}

Latar Belakang Kehidupan Sosial Budaya

Perbedaan antara pria dan wanita dalam peran, fungsi, hak, perilaku dibentuk oleh ketentuan social dan budaya setempat. Untuk mewujudkan kemitra-sejajaran yakni gender dalam bentuk hubungan social antara peran pria dan wanita diperlukan pemberdayaan, khususnya kaum perempuan mengenai hak, kewajiban, peran, tanggung jawabnya serta nilai-nilai dan norma-norma dalam masyarakat. Untuk dapat menjalankan peranannya sebagai pembaharuan yang berdaya guna dan berhasil guna. Wanita perlu mengembangkan diri menjadi pemimpin yang tangguh tanpa meninggalkan kodratnya sebagai perempuan serta menjunjung tinggi harkat dan martabatnya.

Tabel 3.2

\section{Latar Belakang Kehidupan Sosial Budaya}

\begin{tabular}{lll}
\hline No. & \multicolumn{1}{c}{ Pertanyaan } & \multicolumn{1}{c}{ Jawaban } \\
\hline 1. & Komunikasi dengan Keluarga & $\begin{array}{l}\text { Mayoritas menjawab ada komunikasi. } \\
\text { Mayoritas bertemu dengan dengan keluarga rutin } \\
\text { dan hanya 1 orang jarang bertemu dengan } \\
\text { keluarga. }\end{array}$ \\
J. & Intensitas Keluarga & $\begin{array}{l}\text { Jawa }: 11 \text { orang } \\
\text { Betawi }: 1 \text { orang } \\
\text { Sunda }: 2 \text { orang }\end{array}$ \\
3. & Suku Bangsa & $\begin{array}{l}\text { Peran Gender dalam } \\
\text { Kembagian peran sama sesuai dengan tugas dan } \\
\text { tanggung jawabnya }\end{array}$ \\
5. & Pandangan terhadap wanita & $\begin{array}{l}\text { Mayoritas tidak ada yang memandang yang } \\
\text { berbeda terhadap wanita, akan tetapi ada 1 orang } \\
\text { yang memandang berbeda terhadap wanita. }\end{array}$ \\
6. & Wanita dimata budaya & $\begin{array}{l}\text { Mayoritas tidak ada yang menganggap wanita } \\
\text { sebagai kelompok yang pasif/manut oleh budaya. }\end{array}$ \\
\hline
\end{tabular}




\section{Pemahaman tentang Gender di}

\section{Lingkungan Kerja}

Pandangan mengenai gender saat ini sudah tidak lagi menjadi dominan, karena ada banyak peristiwa yang memperlihatkan bahwa pandangan-pandangan tersebut tidak sesuai dengan kenyataan. Banyak pengalaman yang memperlihatkan bahwa kaum wanita juga memiliki kemampuan yang sama dengan pria, dan bahkan kaum wanita dapat memperlihatkan kiprah dan jati dirinya, melalui berbagai karya didunia pekerjaannya.

Pandangan lama harus digantikan dengan pandangan yang baru. Pandangan baru yang dimaksud adalah pandangan yang melihat kaum wanita adalah manusia yang juga memiliki hak dan kesempatan yang sama. Dengan pandangan baru ini segala bentuk diskriminasi yang membatasi ruang

gerak wanita hendaknya dihapuskan dan digantikan dengan pandangan yang memperluas ruang gerak kaum wanita. Kaum wanita tentu memiliki karakter dan gaya yang khas dalam memimpin dan mengambil keputusan sesuai dengan kepribadiannya.

Kiprah kaum perempuan dalam pembangunan sangatlah diperlukan. Selain argumentasi normatif, yang memperlihatkan bahwa kaum wanita memiliki hak dan kesempatan yang sama, terdapat suatu kenyataan bahwa pembagian peran, posisi, nilai-nilai budaya, hak istimewa, dan pandangan di lingkungan kerja tidak ada perbedaan semua sama atau seimbang antara peran wanita dan pria. Hal ini terlihat pada tabel berikut:

Tabel 3.3

Pemahaman tentang Gender di Lingkungan Kerja

\begin{tabular}{|c|c|c|}
\hline No. & Pertanyaan & Jawaban \\
\hline 1. & Pembagian peran & $\begin{array}{l}\text { Pembagian peran antara pria dan wanita adalah sama } \\
\text { disesuaikan dengan tugas dan tanggung jawabnya serta } \\
\text { tidak menutup kemungkinan untuk saling bersaing. }\end{array}$ \\
\hline 2. & Pemahaman $(+)$ atau (-) & $\begin{array}{l}\text { Mayoritas menjawab tidak untuk memiliki pemahaman } \\
(+) \text { atau (-) tentang pembagian peran. }\end{array}$ \\
\hline 3. & Pemahaman "kodrat" wanita & $\begin{array}{l}\text { Mayoritas menjawab kodrat wanita adalah tetap sebagai } \\
\text { ibu yang tetap memperhatikan keluarga, walaupun ia } \\
\text { memiliki pendidikan tinggi atau jabatan dalam } \\
\text { pekerjaannya. }\end{array}$ \\
\hline 4. & Posisi wanita & $\begin{array}{l}\text { Mayoritas para pria mendukung apabila ada wanita } \\
\text { yang ingin maju/berkembang. Dan hanya } 1 \text { orang yang } \\
\text { tidak mendukung wanita untuk maju/berkembang. }\end{array}$ \\
\hline 5. & $\begin{array}{l}\text { Nilai-nilai budaya terhadap } \\
\text { wanita }\end{array}$ & $\begin{array}{l}\text { Nilai-nilai budaya terhadap wanita yang berlaku } \\
\text { dilingkungan kerja mendapat perlakuan yang sama. }\end{array}$ \\
\hline 6. & Hak istimewa & Mayoritas menjawab tidak ada hak istimewa didalam \\
\hline
\end{tabular}




\begin{tabular}{|c|c|c|}
\hline & & $\begin{array}{l}\text { bekerja dan ada } 2 \text { orang yang menjawab ada hak } \\
\text { istimewa didalam bekerja. }\end{array}$ \\
\hline 7. & $\begin{array}{l}\text { Nilai-nilai budaya dikuasai } \\
\text { pria }\end{array}$ & $\begin{array}{l}\text { Mayoritas menjawab nilai-nilai budaya yang berlaku } \\
\text { tidak dikuasai oleh kelompok pria. }\end{array}$ \\
\hline 8. & Kepatuhan & Mayoritas tidak ada kekuasaan pria \\
\hline 9. & $\begin{array}{l}\text { Tanggapan terhadap budaya } \\
\text { pria }\end{array}$ & Mayoritas menjawab budaya pria adalah tegas. \\
\hline 10. & $\begin{array}{l}\text { Pandangan terhadap kaum } \\
\text { pria }\end{array}$ & $\begin{array}{l}\text { Mayoritas pandangan terhadap pria adalah memimpin, } \\
\text { egois, dan bertanggung jawab. }\end{array}$ \\
\hline 11. & Wanita sejajar kaum pria & $\begin{array}{l}\text { Mayoritas setuju jika wanita disejajarkan dengan kaum } \\
\text { pria atau setuju dengan adanya emansipasi wanita. }\end{array}$ \\
\hline
\end{tabular}

\section{Pengambilan Keputusan di Lingkungan} Kerja

Pengambilan keputusan merupakan tindakan yang diputuskan untuk mencegah terjadinya keadaan yang tidak diinginkan atau memperkecil resiko kerugian. Akses dalam pengambilan keputusan adalah bagian dari kondisi-kondisi yang harus dimiliki oleh siapapun.

Dalam pengambilan keputusan perlu dilakukan sistematis dan logis, dimana harus mempertimbangkan resiko atau akibat dari suatu pemilihan masalah.

Struktur dan sistem dari kerangka pengambilan keputusan sangat tergantung pada: (1) Posisi pengambil keputusan; (2) Kedudukan masalah yang dihadapi dan harus dipecahkan; (3) Situasi dimana pengambil keputusan itu berada; (4) Kondisi pengambil keputusan yang meliputi kemampuan dan kekuatannya untuk mengadapi masalah tersebut; dan (5) Tujuan yang harus dicapai dari pengambil keputusan tersebut.

Adanya perbedaan gender antara pria dan wanita tidak menutup kemungkinan untuk mereka mengeluarkan pendapat dan pengambilan keputusan. Hal ini terlihat pada tabel berikut:

Tabel 3.4

Pengambilan Keputusan di Lingkungan Kerja

\begin{tabular}{lll}
\hline No. & \multicolumn{1}{c}{ Pertanyaan } & \multicolumn{1}{c}{ Jawaban } \\
\hline 1. & $\begin{array}{l}\text { Pendapat wanita } \\
\text { diperhatikan }\end{array}$ & $\begin{array}{l}\text { Mayoritas pendapat wanita dilingkungan kerja } \\
\text { sangat diperhatikan, akan tetapi ada 1 orang yang } \\
\text { menjawab tidak memperhatikan pendapat wanita. }\end{array}$ \\
2. & $\begin{array}{l}\text { Peran wanita dalam } \\
\text { pengambilan keputusan }\end{array}$ & $\begin{array}{l}\text { Mayoritas peran wanita sangat dibutuhkan dalam } \\
\text { mengambil keputusan karena memiliki hak dan } \\
\text { tanggung jawab yang sama, akan tetapi ada } 1 \\
\text { orang yang melihat bahwa wanita dominan dalam } \\
\text { mengambil keputusan. }\end{array}$ \\
3. & $\begin{array}{l}\text { Upaya dalam pengambilan } \\
\text { Keputusan }\end{array}$ & $\begin{array}{l}\text { Mayoritas ikut serta memberikan masukan dalam } \\
\text { pengambilan keputusan }\end{array}$ \\
\hline
\end{tabular}


4. Peran wanita sudah optimal

Mayoritas peran serta wanita dalam pengambilan keputusan sudah optimal, akan tetapi 1 orang menjawab belum ada peran serta wanita dalam pengambilan keputusan.

\section{Kesetaraan Gender}

Gender berkaitan dengan proses

keyakinan bagaimana seharusnya laki-laki dan perempuan berperan dan bertindak sesuai dengan tata nilai.
Kesetaraan gender di dalam lingkungan kerja ini, pimpinan tidak memandang berbeda peranan antara pria dan wanita. Begitu juga kebijakan atau peraturan yang ada didalam perusahaan. Hal ini terlihat pada tabel berikut:

Tabel 3.5

Kesetaraan Gender

\begin{tabular}{lll}
\hline No. & \multicolumn{1}{c}{ Pertanyaan } & \multicolumn{1}{c}{ Jawaban } \\
\hline 1. & Kebijakan atau peraturan & $\begin{array}{l}\text { Ada kebijakan atau peraturan yang mencerminkan } \\
\text { adanya kesetaraan gender. }\end{array}$ \\
2. & Peran secara proporsional & $\begin{array}{l}\text { Mayoritas peran agar kesetaraan gender tetap } \\
\text { berjalan proporsional dengan disamakannya tugas } \\
\text { dan tanggung jawabnya. }\end{array}$ \\
3. & Pimpinan & $\begin{array}{l}\text { Pimpinan sejauh ini sudah mengedepankan } \\
\text { kesetaraan gender, akan tetapi ada 1 orang yang } \\
\text { merasa pimpinan } \\
\text { kesetaraan gender. }\end{array}$ \\
\hline
\end{tabular}

\section{KESIMPULAN}

Adapun kesimpulan dalam penelitian kajian tentang peran gender dalam pengambilan keputusan pada era reformasi di institusi kepolisian, yaitu:

1. Selama ini keberadaan perempuan sangat dikesampingkan sekali geraknya tidak pernah dijadikan perhatian, namun ketika melihat dengan pandangan baru dimana wanita memiliki hak dan kesempatan yang sama serta potensi yang dimilikinya maka akan memperluas ruang gerak kaum wanita.Ini dapat dilihat dengan adanya latar belakang kehidupan sosial budaya dan pemahaman tentang gender di lingkungan kerja.

2. Hadirnya sosok perempuan dalam dimensi publik, ingin dunia memperlakukan kaumnya secara proporsional serta tidak menutup kemungkinan untuk mereka mengeluarkan pendapat dan mengambil keputusan. Kaum wanita tentu memiliki karakter dan gaya yang khas dalam memimpin dan mengambil keputusan sesuai dengan kepribadiannya. Kecenderungan inilah yang salah satunya 
berimplikasi pada terstimulusnya kaum perempuan bersaing dengan kaum lakilaki untuk menjadi pemimpin. Ini dapat dilihat dengan adanya pengambilan keputusan di lingkungan kerja dan kesetaraan gender.

\section{DAFTAR PUSTAKA}

Abdullah, Irwan, (Ed); Sangkan Paran Gender, Yogyakarta : PPK UGM Pustaka Pelajar, 2006

Blackburn, Susan; Perempuan Dan Negara Dalam Era Indonesia Modern, Australia : Cambridge University Press, 2009

Gamble, Sarah; Pengantar Memahami Feminism Dan PostFeminisme, Jakarta : Jalasutra, 2010
Gusnita, Wiwik; Pengaruh Kontribusi Ekonomi Perempuan dan Gender Terhadap Pendapatan Keluarga, Bogor : Pascasarjana IPB, 2011

Hubeis, Aida, Vitayala, S; Pemberdayaan Perempuan dari Masa ke Masa, Bogor : IPB Press, 2010

ILO; Konvensi-Konvensi ILO Tentang Kesetaraan Gender Di Dunia Kerja, ILO Jakarta, 2006

Puspitawati, Herien; Fahmi, Sri, Andriyani; Jurnal Ilmu Keluarga Dan Konsumen Departemen Ilmu Keluarga dan Konsumen FEMA IPB, Vol. 1 No. 2, Agustus 2008

Ritzer, George; Goodman, Douglas, J;Teori, Sosiologi Modern, Jakarta : Kencana, 2010 